\title{
THE PERFORMANCE OF LAYING HENS FED DIFFERENT CALCIUM SOURCE
}

\author{
S. Kismiati ${ }^{1,2}$, T. Yuwanta ${ }^{1}$, Zuprizal $^{1}$ and Supadmo ${ }^{1}$ \\ ${ }^{1}$ Faculty of Animal Science, Gadjah Mada University \\ Jl. Fauna 3 Bulaksumur 55281 Yogyakarta - Indonesia \\ ${ }^{2}$ Permanent Address: Faculty of Animal Science and Agriculture, Diponegoro University, \\ Tembalang Campus, Semaran, 50275 - Indonesia \\ Corresponding E-mail : kismiati59@gmail.com
}

Received October 09, 2012; Accepted November 20, 2012

\begin{abstract}
ABSTRAK
Penelitian bertujuan untuk mengevaluasi penampilan produksi ayam petelur yang diberi pakan dengan sumber kalsium berbeda. Penelitian menggunakan 200 ekor ayam petelur strain Isa Brown umur 25 minggu. Ayam dipelihara didalam kandang batre individual selama 12 minggu. Empat sumber kalsium (batu kapur sebagai kontrol, 5\% batu kapur $+2,5 \%$ limbah kerabang telur, 2,5\% batu kapur + $5 \%$ limbah kerabang telur, dan 7,5\% limbah kerabang telur) digunakan dalam pakan penelitian. Rancangan pecobaan yang digunakan yaitu Rancangan Acak Lengkap dengan 4 perlakuan dan 5 ulangan. Setiap unit percobaan terdiri dari 10 ekor ayam petelur. Parameter yang diukur yaitu konsumsi pakan, konsumsi protein, konsumsi kalsium, konsumsi fosfor, produksi telur, berat telur dan konversi pakan. Hasil penelitian menunjukkan bahwa penggunaan 7,5\% limbah kerabang telur sebagai sumber kalsium meningkatkan konsumsi pakan, konsumsi kalsium, konsumsi fosfor, produksi telur dan berat telur kecuali konversi pakan. Kesimpulan dari penelitian ini adalah penggunaan limbah kerabang telur sebagai sumber kalsium pakan ayam petelur menghasilkan performa produksi lebih baik dibanding menggunakan batu kapur dan campuran batu kapur dengan limbah kerabang telur.

Kata kunci : kalsium, limbah kerabang telur, penampilan, produksi.
\end{abstract}

\begin{abstract}
The research was aimed to evaluate the performance of laying hens fed different calcium sources. Two hundreds of Isa Brown laying hens were used in this study. The hens were raised in individual battery cages units for 12 weeks. Four calcium source (limestone as a control, 5\% limestone $+2.5 \%$ eggshells waste, $2.5 \%$ limestone $+5 \%$ eggshells waste and $7.5 \%$ eggshell waste) were used in feed experiment. A completely randomized design was applied, with 4 treatments and 5 replications. Each experimental unit consisted of 10 laying hens. The parameters measured were feed intake, protein intake, calcium intake, phosphorus intake, egg production, egg weight and feed conversion ratio. Results of the research showed that the calcium source had significantly effect on performance productions. The use of eggshell waste $7.5 \%$ significantly increased the feed intake, calcium intake, phosphorus intake, egg production and egg weight except for feed conversion ratio. The conclusion of this research was that the use of eggshell waste as calcium source of feed resulted in better performance than using limestone or mixed limestone with eggshell waste.
\end{abstract}

Keywords : Calcium, eggshell waste, performance

\section{INTRODUCTION}

Laying hens need high calcium (Ca) especialy during egg production. Calcium is essential for egg formation. Leeson and Summers (2005) stated that deficiency of calcium resulted in decrease egg production and mobilization of calcium from bone. The release of calcium from bones is along with phosphorus (P). Egg production will return to normal in 6 to 8 days after hens receiving a diet adequate in calcium. Medullary bone is a woven bone that acts as a labile source of calcium for eggshell formation (Whitehead, 2004). The nutritional role of $\mathrm{Ca}$ is closely linked to that of phosphorus and to the effect of vitamin D (Arajuo et al., 2005 in Pelicia 
et al., 2009). Calcium requirement of the laying hens is 3-4.5 g/hen/day and phosphorus/non phythate phosphorus requirement is 250 mg/hen/day (NRC, 1994).

Couto et al. (2008) stated that calcium source effect on egg production. The use of calcium carbonate produced higher egg production than dicalcium phosphate (Silva and Santos, 2000). Supplementation of $50 \%$ limestone with oyster shell increased egg production (Ahmad and Balander, 2003). Marine calcium can replace up to $45 \%$ of calcitic limestone with no effects on performance or egg quality (Pelicia et al., 2007). Lesson and Summers (2005), Safaa et al. (2008) and Saunders-Blades et al. (2009), stated that limestone and oyster shell could be used as a source of calcium for hens feed with no effect on egg production. Oyster shell and limestone both provide $\mathrm{Ca}$ in the form of $\mathrm{Ca}$ carbonate, and each contain about $38 \%$ of $\mathrm{Ca}$ (NRC, 1994). Leeson and Summers (2005) stated that oyster shell is more expensive than limestone.

Ogawa et al. (2004) stated that eggshell contains $94.4 \% \quad \mathrm{Ca} \quad \mathrm{CO}_{3}, \quad 0.73 \% \mathrm{Ca}_{3}\left(\mathrm{PO}_{4}\right)_{2}$, $0.84 \% \mathrm{Mg} \mathrm{CO}_{3}$ and $3.3 \%$ protein. According to Gongruttananun (2011) eggshell contains 5.35\% protein, $34.89 \%$ calcium and $0.001 \%$ phosphorus. The research results of Schaafsma et al. (2000) showed that eggshell powder contains minerals (Ca, Mg, P, Sr, Zn, Fe, B, Cr, F, Se, N, F and V), protein, amino acids and hormones. The hormones of the eggshell are calcitonin (10-25 $\mathrm{ng} / \mathrm{g})$ and progesterone (0.30 to $0.33 \mathrm{ng} / \mathrm{g})$. Nakano et al. (2001) stated that eggshell contains glycosaminoglycans and calcium. The research of Nakano et al. (2002) found galactosaminogycan in eggshell. Nakano et al. (2003) stated that amino acids contained within the eggshell are threonine, serine, glycine, methionine, alanine, isoleucine, valine, tyrosine, phenylalanine, histidine, lysine, arginine, proline and hydroxyproline. Davis et al. (2008) stated that the eggshell contained Salmonella. The cooking temperature of $82.5^{\circ} \mathrm{C}$ can kill Salmonella of eggshell. Kismiati et al. (2012) reported that fortification phosphorus with $\mathrm{H}_{3} \mathrm{PO}_{4} 5 \%$ increased phosphorus content and kill bacteria of the eggshell. Phosphorus is a critical aspect of laying hen nutrition in hot climates (Usayran et al. 2001). Phosphorus from animal products is generally considered to be well utilized (NRC, 1994). Snow et al. (2004) stated that phosphorus level of the feed affected on egg production. Kingori (2011) stated that eggshell can affect environmental pollution. In Indonesia there were about 75,112 tons of laying hens eggshell waste, 18,620 tons of indigenous hens eggshell waste and 18,986 tons of duck eggshell waste every year (Direktorat Jenderal Peternakan dan Kesehatan Hewan, 2011). Laying hen eggshell waste product was higher than eggshell waste of indigenous chicken and ducks.

The aim of the research was to evaluate the performance of laying hens fed different calcium source. The calcium sources were limestone, mixed of limestone and eggshell waste and eggshell waste. Utilization of eggshell waste as a calcium source of feed is expected to reduce environmental pollution.

\section{MATERIALS AND METHODS}

Eggshells waste were collected from several bakeries and then soaked in the water at temperature of $80^{\circ} \mathrm{C}$ for 15 minutes, drained and then soaked in $\mathrm{H}_{3} \mathrm{PO}_{4} 5 \%$ for 15 minutes. After that the eggshell were dried in the sun for 3 days, ground and then used as a calcium source of feed.

Two hundred of laying hens (Isa Brown strain) aged 25 weeks were raised in battery cages (single cage) during 12 weeks. The hens were distributed in a completely randomized design with 4 treatments and 5 replications. Each experimental unit consisted of 10 laying hens were subjected in the following each treatments: T1: $7.5 \%$ limestone as control, T2: $5 \%$ limestone $+2.5 \%$ eggshell waste, T3 : 2.5 limestone $+5 \%$ eggshell waste and T4 : 7.5\% eggshell waste as a source of calcium.The composition of feedstuffs and nutrients content of feed used are presented in Table 1.

The parameters measured were feed intake, protein intake, calcium intake, phosphorus intake, egg production, egg weight and feed conversion ratio. Feed intake, protein intake, calcium intake, phosphorus intake were recorded weekly, egg production was recorded daily. Egg weight and feed conversion ratio were measured using all eggs produced during 3 days at the end of week 4, 8 and 12 . The data were analyzed by ANOVA. Duncan's Multiple Range Test was used in mean comparison when found effect of treatment.

\section{RESULTS AND DISCUSSION}

Table 2 shows that the use of different calcium source in feed had significant effect 
Table 1. The Ingredients and Calculated Composition of the Experimental Diet

\begin{tabular}{|c|c|c|c|c|}
\hline \multirow[b]{2}{*}{ Ingredients } & \multicolumn{4}{|c|}{ Dietary Treatments } \\
\hline & $\mathrm{T} 1$ & $\mathrm{~T} 2$ & $\mathrm{~T} 3$ & $\mathrm{~T} 4$ \\
\hline & & 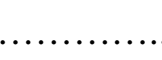 & 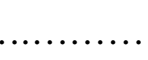 & $\ldots$ \\
\hline Corn & 70.00 & 70.00 & 70.00 & 70.00 \\
\hline Soybean extract & 10.00 & 10.00 & 10.00 & 10.00 \\
\hline Poultry Meat Meal & 11.00 & 11.00 & 11.00 & 11.00 \\
\hline Dicalcium Phosphat & 1.00 & 1.00 & 1.00 & 1.00 \\
\hline Limestone & 7.50 & 5.00 & 2.50 & 0.00 \\
\hline Eggshell waste & 0.00 & 2.50 & 5.00 & 7.50 \\
\hline Topmix* & 0.25 & 0.25 & 0.25 & 0.25 \\
\hline Salt & 0.25 & 0.25 & 0.25 & 0.25 \\
\hline Calculated Composition & 100.00 & 100.00 & 100.00 & 100.00 \\
\hline $\mathrm{ME}(\mathrm{kcal} / \mathrm{kg})$ & 2892.50 & 2892.50 & 2892.50 & 2892.50 \\
\hline Crude Protein (\%) & 16.17 & 16.31 & 16.45 & 16.59 \\
\hline $\mathrm{Ca}(\%)$ & 3.44 & 3.44 & 3.44 & 3.44 \\
\hline $\mathrm{P}$ available $(\%)$ & 0.46 & 0.50 & 0.55 & 0.59 \\
\hline
\end{tabular}

* Methionine, lysine, vitamin A, D3,E, K, B1, B2, B6, B12, C, Ca-pantothenat, Niacin, Cholin Chloride Mn, $\mathrm{Fe}, \mathrm{I}, \mathrm{Zn}, \mathrm{Co}, \mathrm{Cu}$, Santoquin and Zinc Bacitracin.

$(\mathrm{P}<0.05)$ on all the performance parameters (feed intake, protein intake, calcium intake, phosphorus intake, egg production and egg weight) of laying hens, except for feed conversion ratio.

\section{Feed Intake}

The use of $7.5 \%$ limestone (T0), $5 \%$ limestone $+2.5 \%$ eggshell (T1) and $2.5 \%$ limestone $+5 \%$ eggshells (T2) in the feed of laying hens had no significant effect $(\mathrm{P}>0.05)$ on feed intake, but the use of 7.5\% eggshells (T3) increased feed intake significantly $(\mathrm{P}<0.05)$. The use of $5 \%$ limestone $+2.5 \%$ eggshell increased protein content of the feed by $0.14 \%$, the use $2.5 \%$ limestone $+5 \%$ eggshell increased protein content of the feed by $0.2 .8 \%$ and the use of $7.5 \%$ eggshell increased protein content of feed by $0.42 \%$ (Table 1). The results of this research showed that the increasing of 0.14 and $0.28 \%$ protein from eggshell had not been able to increase feed intake, while the increasing of $0.42 \%$ protein increased feed intake. Gunawardana et al. (2008) reported that the increasing of protein level caused the increase of feed intake.

Nakano et al. (2003) reported that the decalcified eggshell and shell membrane contained threonine, serine, galactosamine, glycine, alanine, valine, methionine, isoleucine, leucine, tyrosine, phenylalanine, histidine, lysine, arginine, proline, and hydroxyproline. This study used eggshell without decalcification. The study of Corzo and Kidd (2004) showed that the addition of lysine increase feed intake and glycine supplementation increase feed intake. Faria et al. (2002) stated that amino acids increased feed intake of laying hens. The research of Bonekamp et al. (2010) showed that lysine, methionine, cystine, threonine, tryptophan, isoleucine, arginine and valine increased feed consumption.

Eggshell contains $4.5 \mathrm{mg} / \mathrm{g} \mathrm{Mg}, 5.13 \mu \mathrm{g} / \mathrm{g}$ $\mathrm{Zn}, 22.4 \mu \mathrm{g} / \mathrm{g} \mathrm{Fe}, 7.7 \mu \mathrm{g} / \mathrm{g} \mathrm{Cu}$, and $23.5 \mathrm{ng} / \mathrm{g} \mathrm{Se}$ (Schaafsma et al., 2000). According to NRC (1994), $\mathrm{Mg}, \mathrm{Cu}, \mathrm{Se}$, and $\mathrm{Zn}$ are the essential minerals for poultry. Maciel et al. (2010) stated that organic $\mathrm{Zn}, \mathrm{Cu}, \mathrm{Mn}$ increased feed intake of laying hens. The addition of $0.3 \mathrm{ppm}$ organic Se and $60 \mathrm{ppm}$ organic $\mathrm{Zn}$ in feed increased feed 
Tabel 2. The Effect of Different Calcium Source on the Performance

\begin{tabular}{lccrc}
\hline Parameters & \multicolumn{4}{c}{ Treatments } \\
\cline { 2 - 5 } & \multicolumn{1}{c}{ T0 } & \multicolumn{1}{c}{ T1 } & \multicolumn{1}{c}{ T3 } \\
\hline Feed intake (g/hen/day) & $104.76^{\mathrm{b}}$ & $107.13^{\mathrm{b}}$ & $109.10^{\mathrm{b}}$ & $116.81^{\mathrm{a}}$ \\
Protein intake (g/ hen /day) & $16.94^{\mathrm{c}}$ & $17.46^{\mathrm{bc}}$ & $17.91^{\mathrm{b}}$ & $19.37^{\mathrm{a}}$ \\
Calcium intake (g/ hen /day) & $3.60^{\mathrm{b}}$ & $3.69^{\mathrm{b}}$ & $3.75^{\mathrm{b}}$ & $4.02^{\mathrm{a}}$ \\
Phosphorus intake (g/ hen /day) & $0.48^{\mathrm{b}}$ & $0.54^{\mathrm{b}}$ & $0.55^{\mathrm{b}}$ & $0.64^{\mathrm{a}}$ \\
Egg production (\%) & $86.83^{\mathrm{b}}$ & $87.95^{\mathrm{b}}$ & $87.07^{\mathrm{b}}$ & $91.42^{\mathrm{a}}$ \\
Egg weight (g) & $53.30^{\mathrm{b}}$ & $52.90^{\mathrm{b}}$ & $54.99^{\mathrm{ab}}$ & $55.73^{\mathrm{a}}$ \\
Feed conversion ratio & 2.26 & 2.30 & 2.28 & 2.29 \\
\hline
\end{tabular}

Different superscript at the same raw indicates differ significantly $(\mathrm{P}<0.05)$

intake of quail (Cruz and Fernandez, 2011). The increasing of Se content in the feed (from 0.55 to $0.57 \mathrm{mg} / \mathrm{kg}$ ) increased feed intake (Scheideler et al., 2010).

\section{Protein Intake}

Table 2 presented that protein intake increased due to the increase of feed intake. Result of this research in agreement with Novak et al. (2006) that protein intake linearly increased as feed intake increased. The other factor of protein intake is protein content of the feed. The use of eggshell waste increased protein content of the feed (Table 1). Hudson et al. (2000) stated that protein intake is influenced by the protein content of feed. Gunawardana et al. (2008) reported that dietary protein level had a significant effect on protein intake.

\section{Calcium and Phosphorus Intake}

Calcium and phosphorus intake were not significantly different in the use of limestone $7.5 \%$ (T0), $5 \%$ limestone $+0.25 \%$ eggshell $(\mathrm{T} 1)$ and $2.5 \%$ limestone $+5 \%$ eggshell (T2), but increased significantly in the use of $7.5 \%$ eggshell (T4). The increasing of calcium intake was caused by the increase of feed intake, whereas the increase of phosphorus intake was caused by the increase of feed intake (Table 2) and phosphorus content of the feed (Table 1). Increasing phosphorus from 0.044 to $0.088 \%$ (T0 to T2) in feed had no effect on the phosphorus intake, but the increase of phosporus by $0.13 \%$ (T0 to T3) increased phosphorus intake significantly (Table
2). Pelicia et al. (2009) reported that calcium and phosphorus intake is influenced by the calcium and phosphorus level of feed. Increasing calcium of the feed by $3-5 \%$ increased calcium intake 1.77 $\mathrm{g} / \mathrm{hen} /$ day and increasing phosphorus of feed from 0.25 to $0.4 \%$ increase phosphorus intake to 0.19 $\mathrm{mg} /$ hen/day.

\section{Egg Production and Egg Weight}

Eggs production and egg weight in the feed containing of $7.5 \%$ limestone, $5 \%$ limestone + 0,25 eggshell and $2.5 \%$ limestone $+5 \%$ eggshell (T0, T1, T2) were not different sinificantly, while the use of $7.5 \%$ eggshell (T3) increased egg production and egg weight significantly $(\mathrm{P}<0.05)$. The increasing of egg production and egg weight was caused by the protein, calcium, and phosphorus intakes. This is in agreement with the study of de Beer and Coon (2006) that hens fed high protein had higher egg production. Research of Adeyemo et al. (2012) indicated that there were a direct relationship between protein intake and performance of laying hen at the first production. Joseph et al. (2000) suggested that the high protein level in feed result high egg production. Novak et al. (2006) and Gunawardana et al. (2008) reported that protein had a significant effect on egg production and egg weight. Increasing protein intake significantly increased egg production and egg weight. Kingori et al. (2010) reported that feed protein affects on egg production. Increased protein by $100-120 \mathrm{~g} / \mathrm{kg}$ dry matter increases egg production, but the increase of 120 and $140 \mathrm{~g} / \mathrm{kg}$ dry matter does not increase 
the egg production, even $170 \mathrm{~g} / \mathrm{kg}$ dry matter of egg production is lower than $100 \mathrm{~g} / \mathrm{kg}$ dry matter. Nahashon et al. (2007) stated that hens on 22 and $24 \%$ crude protein diets exhibited higher egg production than those on $20 \%$ crude protein diets. Eggshell contains various amino acids (Nakano et al., 2003). Egg production and egg weigh influenced by amino acids content of feed (Faria et al., 2002). Corzo and Kidd (2004) stated that glycine supplementation increases egg production and egg weight. The research results of Bonekamp et al. (2010) showed that lysine, methionine, cystine, threonine, triptophan, isoleusine, arginine and valine increase feed consumption, egg production and egg weight. Glycine supplementation increases egg production (Han and Thacker, 2011).

The use of $7.5 \%$ eggshell increased calcium and phosphorus intake. Squires (2003), Leeson and Summers (2005) stated that calcium and phosphorus are very important for the egg formation especially eggshell. Calcium metabolism requires proteins to $\mathrm{Ca} \mathrm{BP}$ (calcium binding protein) formation. Furthermore, Leeson and Summers (2005) stated that if poultry has calcium deficiency so the egg production will decrease. Egg production will return to normal in 6 to 8 days after hens receive a diet adequate in calcium. Phosphorus is a mineral that is always paired with calcium. The ratio of $\mathrm{Ca}$ and $\mathrm{P}$ in feed should be balanced, the high $\mathrm{P}$ content will reduce the availability of $\mathrm{Ca}$, because $\mathrm{Ca}$ is easily digested in acid. Roland et al. (2003) stated that the decrease in phosphorus content of feed from $0.4-0.1 \%$ decreased egg production. Phosphorus is an element to form energy and has an important role in the metabolism of carbohydrates, amino acids and fat, metabolism of nerve tissue, normal blood chemistry, the growth of the skeleton and fat transport of other lipids. All chemical reactions in the cell require energy, and this can be established by means of an overhaul of Adenosine Tri Phosphate (ATP) (Muray, 2003). Phosphorus has interaction with other minerals i.e. $\mathrm{Mg}$ and vitamin D (Higdon, 2003). Linder (1984) stated that approximately $60 \%$ of $\mathrm{Mg}$ is in bone and the rest mainly in the soft tissue cells with the main function to stabilize the structure of ATP in enzyme reactions that require ATP. The use of $7.5 \%$ eggshell in feed replaces total limestone. The result of this research showed that the quality of calcium eggshell was better then limestone. Similarly, eggshell phosphorus had high availability. Rovenský et al. (2003) stated that the bioavailability of calcium from eggshell is better than purified calcium carbonate. Phosphorus is major inorganic constituents of the avian eggshell (Cusack, et al., 2003). Supplementation of inorganic phosphorus supported optimal egg production ( Snow et al., 2003). Kerstetter et al. (2003) suggested that the increase of protein intake increases calcium absorption in small intestine. Calcium, phosphorus and protein intake increased in applied eggshell $7.5 \%$ (feed 4), therefore obtained the highest egg production.

Eggshell also contains $\mathrm{Mg}, \mathrm{Fe}, \mathrm{Zn}, \mathrm{Se}, \mathrm{Cu}$ and Mn, so the use of 7.5\% eggshell in feed (T3) increased egg production. According to Gaa'l et al. (2004), Mg is involved in many biochemical processes, including as the phosphate activator and the metabolism of carbohydrates. $\mathrm{Mg}$ intake can increase the digestibility of feed and increase egg production. Ogawa et al. (2004) stated that $\mathrm{Mg}$ in eggshell is bound with carbonate to form $\mathrm{MgCO}_{3}$. According to Leeson and Summers et al. (2005), $\mathrm{MgCO}_{3}$ is an available $\mathrm{Mg}$. Zinc is a very important mineral in biological processes in the body of poultry and $\mathrm{Zn}$ is an essential component of several enzymes, and it has both structural and catalytic function in metalloenzymes. $\mathrm{Zn}$ binds protein and acts as the coenzyme (Sahin et al., 2009). Se binds proteins in cells are associated with glutathione, thiamine and biotin (Georgievskh et al., 1982). According to Murray et al. (2003) enzyme plays an important role in physiological processes. Many enzymes requiring coenzyme that acts to increase the catalytic ability to become bigger. Metal ions participate in increasing the chemical reaction speed of enzymes. Metal ions most involved in enzymatic catalysis are $\mathrm{Fe}, \mathrm{Mg}$, Co (in coenzyme B12) and $\mathrm{Mn}$. Increasing Se in feed $(0.55$ to $0.75 \mathrm{mg} / \mathrm{kg})$ had a positive effect on egg production and egg weight. Se source had no significant effect on egg production and egg weight (Scheideler et al., 2010). Se has the role for the health, growth and the body's physiological processes. Organic Se has higher bioavailability than inorganic $\mathrm{Se}$ (Utterback et al., 2005). Se is an essential part of glutathione peroxides (GPx), which controls the activity of metabolism. Egg production was affected by Se level of feed. Egg production was greater in hens feed $0.3 \mathrm{mg} / \mathrm{kg}$ than $0.1 \mathrm{mg} / \mathrm{kg}$ of Se (Leeson et al., 2008).

\section{Feed Conversion Ratio}

The use of different calcium source had no 
effect on feed conversion ratio. Feed conversion ratio was not significantly different due to the increase of feed intake, protein, calcium and phosphorus intake and is followed by an increase in egg production and egg weight significantly. Kingori et al. (2010) stated that protein level of feed had not significantly effect on feed conversion ratio although it increased egg production. According to Pelcia et al. (2009), the increased $\mathrm{Ca}$ intake of $0.60 \mathrm{~g} / \mathrm{hen} /$ day did not improve feed conversion ratio, however, increased intake of $\mathrm{Ca}$ from 3.78 to $5.55 \mathrm{~g} / \mathrm{hen} /$ day increased feed conversion ratio. Increased phosphorus intake from 0.13 to $0.5 \mathrm{mg} / \mathrm{hen} /$ day did not affect feed conversion ratio. In this study, increased $\mathrm{Ca}$ intake from 3.60 to $4.02 \mathrm{~g} / \mathrm{hen} / \mathrm{day}$ and phosphorus intake of 0.48 to $0.64 \mathrm{mg} / \mathrm{hen} /$ day did not result in a change of feed conversion ratio. The results showed that the use of $7.5 \%$ eggshell was efficient in terms of feed conversion ratio

\section{CONCLUSION}

The results of this study indicate that the eggshell waste would be suitable sources of calcium for laying hens. The use of $7.5 \%$ eggshell waste increase feed intake, protein intake, calcium and phosphorus intake, egg production and egg weight but not increase feed conversion ratio.

\section{ACKNOWLEDGMENTS}

The authors would like to thank Dr. A. Hintono for providing facilities of this research, A.B. Prasetya and F. Widiatmoko for helping in data collection in this research.

\section{REFERENCES}

Adeyemo, G. O., S. A. Abioye and F. A. Aderemi. 2012. The effect of varied dietary crude protein levels with balanced amino acids on performance and egg quality characteristics of layers at first laying phase. Food and Nut. Sci. 3: 526-529.

Ahmad. H.A. and R.J. Balander. 2003. Alternative feeding regimen of calcium source and phosphorus level for better eggshell quality in commercial layers. J. Appl. Poult. Res. 12:509-514.

Bonekamp, R. P., A. Lemme, P. J. Wijtten and J. K. Sparla. 2010. Effects of amino acids on egg number and egg mass of brown (heavy breed) and white (light breed) laying hens.
Poult. Sci. 89:522-529.

Corzo, A and M.T Kidd. 2004. Starter dietary lysine level and strain cross effects on performance and carcass traits of broiler females. Brazilian J. Poult. Sci. 6(2):73 -97.

Couto, H. P., V. L. H. Nery, J. B. Fonseca J. Chiquieri, L. C. R. Carneiro, Cláudio and T. Lombardi. 2008. Alternative sources of calcium and phosphorus for commercial laying hens. R. Bras. Zootec. 37(8):14191423.

Cusack, M., A.C. Fraser and T. Stachel. 2003. Magnesium and phosphorus distribution in the avian eggshell. Comparative Biochem. Physiol. Part B. 134: 63-69.

Davis, A.L., P.A. Curtis, D.E. Conner, S.R. McKee and L.K.Kerth. 2008. Validation of cooking method using shell egg inoculated with salmonella serotypes enteritidis and heidelberg. Poult. Sci. 87:1637-1642.

de Beer, M. and C. N. Coon. 2006. The effect of increased protein intake during the starter and prebreeder periods on reproductive performance of ultra high yield broiler breeder hens. Int. J. Poult. Sci. 5 (9): 812821.

Direktorat Jenderal Peternakan dan Kesehatan Hewan. 2011. Statistik Peternakan. Direktorat Jenderal Peternakan dan Kesehatan Hewan, Departemen Pertanian, Republik Indonesia.

Faria, D.E., R.H. Harms and G.B. Russell. 2002. Layer performance recovery after feeding amino acid-deficient diets. Brazilian J. Poul. Sci.. 4(2):141-148.

Gaal, K.K., O. Safar, L. Gulyas and P. Stadler. 2004. Magnesium in animal nutrition. J. the American College of Nutrition. 23(6):754757.

Georgievskh, V. I., B. N. Ankenkov, and V.T. Samokhin. 1982. Mineral Nutrition of Animals. English Translation Butterworth and Co Publisher.

Gongruttananun, N. 2011. Effects of eggshell calcium on productive performance, plasma calcium, bone mineralization, and gonadal characteristics in laying hens. Poult. Sci. 90:524-529.

Gunawardana, P., D. A. Roland Sr. and M. M. Bryant. 2008. Effect of energy and protein on performance, egg components, egg solids, egg quality, and profits in molted HyLine W-36 Hens. J. Appl. Poult. Res. 17:432-439. 
Han, Y. and P. A. Thacker. 2011. Influence of energy level and glycine supplementation on performance, nutrient digestibility and egg quality in laying hens. Asian-Aust. J. Anim. Sci. 24(10):1447-1455.

Higdon, J. 2003. Phosphorus. Linus Pauling Institute, Oregon State University.

Hudson, B. P., R. J. Lien and J. B. Hess. 2000. Effects of early protein intake on development and subsequent egg production of broiler breeder hens. J. Appl. Poult. Res. 9:324-333.

Joseph. N. S., F. E. Robinson, D. R. Korver and R. A. Renema. 2000. Effect of dietary protein intake during the pullet-to-breeder transition period on early egg weight and production in broiler breeders. Poult. Sci. 79:17901796.

Kerstetter, J. E. , K. O. O'Brien and L. I. Karl. 2003. Dietary protein, calcium metabolism, and skeletal homeostasis revisited. Am. J. Clin. 78:84-92.

King'ori, A.M. 2011. A Review of the uses of poultry eggshells and shell membranes. Int. J. Poult. Sci. 10 (11): 908-912.

King'ori, A.M., J.K. Tuitoek, H.K. Muiruri and A.M. Wachira. 2010. Effect of dietary crude protein levels on egg production, hatchability and post-hatch offspring performance of indigenous chickens. Int. J. Poult. Sci. 9(4):324-329.

Kismiati, S., T. Yuwanta, Zuprizal and Soepadmo. 2012. The physical characteristics and chemical of eggshell waste as phosphorus fortification: Its effect on egg production and egg quality of laying hens. Proc. the $1^{\text {st }}$ Poult. Int. Seminar, Padang-West Sumetara, 11-12 September 2012. p.136-143.

Leeson, S. and J. D. Summers. 2005. Commercial Poultry Nutrition 3rd Edition. Uni versity Books Guelph, Ontario, Canada.

Leeson, S., H. Namkung, L. Caston, S. Durosoy, and P. Schlegel. 2008. Comparison of selenium levels and sources and dietary fat quality in diets for broiler breeders and layer hens. Poult. Sci. 87:2605-2612.

Linder, M. C. 1984. Nutritional Biochemistry and Metabolism with Clinical Applications. Elsevier Publishing Company, Inc. New York.

Maciel, M. P., E. P. Saraiva, E. F. Aguiar, P. A. P. Ribeiro, D. P. Passos and J. B. Silva. 2010. Effect of using organic micro minerals on performance and external quality of eggs of commercial laying hens at the end of laying. R. Bras. Zootec. 39(2):344-348.

Murray, R. K.,D.K. Granner, P. A. Mayes and V.W. Rodwell. 2003. Biokimia Harpers. Edisi 25. E G C Jakarta.

Nakano, T., N. Ikawa and L. Ozimek. 2001. Extraction of glycosaminoglycans from chicken eggshell. Poult. Sci. 80:681-648.

Nakano, T., N. Ikawa and L. Ozimek. 2002. Galactosaminoglycans composition in chicken eggshell. Poult. Sci. 81;709-714.

Nakano, T., N.I. Ikawa and L. Ozimek. 2003. Chemecal compisition of chicken eggshell and shell membranes. Poult. Sci. 82:510514.

Nahashon, S.N. N. Adefope, A. Amenyenu and D. Wright. 2007. Effec of metabolizable energy and crude protein concentrations in diets of pearl gray guinea fowl pullets. 2. Egg production performance. Poult. Sci. 86:973982.

Novak C, H. M. Yakout and S. E. Scheideler. 2006. The effect of dietary protein level and total sulfur amino acid : lysine ratio on egg production parameters and egg yield in HyLine W-98 hens. Poult. Sci. 85(12):2195206.

NRC. 1994. Nutrient Requirement of Poultry. Ninth revised edition. National Academy Press. Washington, D.C.

Ogawa H., M. Uehera, T Kuwayama, M. Kawashima and K. Tanaka. 2004. Change in Calcium, Magnesium and Phosphorus contents of eggshell during stay in oviduct uterus in the guinea fowl and the chicken. J. Poult. Sci. 41: 236 -240.

Pelícia K, E. A.Garcia, M. R. S. Scherer, C. Móri, J. A. Dalanezi, A. B. G. Faitarone, A. B. Molino and D. A. Berto 2007 Alternative calcium source effects on commercial egg production and quality. Rev. Bras. Cienc. Avic. 9(2):105-109.

Pelicia, K. , E.A. Garcia, A.B.G. Faitarone, A.P. Silva, D.A. Berto, A.B. Molino and F. Vercese. 2009. Calcium and available phosphorus levels for laying hens in second production cycle. Brazilian J. Poult. Sci. 11(1): 39-49

Roland Sr, D. A., H. A. Ahmad, S. S. Yadalam, and T. Sefton. 2003. Effect of nongenetically modified phytase supplementation on commercial leghorns. J. Appl. Poult. Res. 12:257-263. 
Rovenský J, M. Stancíková, P. Masaryk, K. Svík and R. Istok . 2003. Eggshell calcium in the prevention and treatment of osteoporosis. Abstract. Int. J. Clin. Pharmacol. Res. 23(23):83-92.

Sahin, K., N. Sahin, O. Kucuk, A. Hayirly and A. S. Prasad. 2009. Role of dietary zinc in heatstressed poultry. Poult. Sci. 88: 2176-2183

Schaafsma, A., I. Pakan., G.J.H. Hofstede, F.A.J. Muskiet, E. Van Der Veer and P.J.F. De Vries. 2000. Mineral, amino acid, and hormonal composition of chicken eggshell powder and the evaluation of its used in human nutrition. Poult. Sci. 79:1833-1838.

Safaa, H. M., M. P. Serrano, D. G. Valencia, M. Frikha, E. Jiménez-Moreno and G. G. Mateos. 2008. Productive performance and egg quality of brown egg-laying hens in the late phase of production as influenced by level and source of calcium in the diet Poult. Sci.: 87:2043-2051.

Saunders-Blades, J. L., J. L. Maclsaac, D. R Korver and D. M. Anderson. 2009. The effect of calcium source and particle size on the production performance and bone quality of laying hens. Poult. Sci. 88 :338353.

Scheideler, S. E., P. Weber and D. Monsalve. 2010. Supplemental vitamin E and selenium effects on egg production, egg quality, and egg deposition of $\alpha$-tocopherol and selenium. J. Appl. Poult. Res. 19:354-360.

Silva, J. H. V and V. J. Santos. 2000. Effect of calcium carbonate on the egg shell quality during the forced molt. Rev. Bras. Zootec. 29 (5):1440-1445

Snow, J. L., M. W. Douglas, A. B. Batal, M. E. Persia, P. E. Biggs and C. M. Parsons. 2003. Efficacy of high available phosphorus corn in laying hen diets. Poult. Sci.82:1037-1041.

Snow, J. L., M. W. Douglas, K. W. Koelkebeck, A. B. Batal, M. E. Persia, P. E. Biggs and C. M. Parsons. 2004. Minimum phosphorus requirement of one-cycle and two-cycle (molted) hens. Poult. Sci. 83:917-924.

Squires, E. J. 2003. Applied Animal Endocrinology. CABI Publishing.

Usayran, N., M. T. Farran, H. H. O. Awadallah, I. R. Al-Hawi, R. J. Asmar and V. M. Ashkarian. 2001. Effects of added dietary fat and phosphorus on the performance and egg quality of laying hens subjected to a constant high environmental temperature. Poult. Sci. 80:1695-1701.

Utterback, P. L. C. M. Parsons, I. Yoon and J. Butler. 2005. Effect of supplementing selenium yeast in diets of laying hens on egg Selenium content. Poult. Sci. 84:1900-1901.

Whitehead, C. C. 2004. Overview of bone biology in the egg laying hen. Poult. Sci. 83:193199. 